\title{
Diabetic retinopathy and visual disabilities among patients in a rehabilitation program
}

\author{
Retinopatia diabética e deficiência visual entre \\ pacientes de programa de reabilitação
}

Zelia Zilda Lourenço de Camargo Bittencourt ${ }^{1}$, Rita de Cássia Letto Montilha ${ }^{1}$, Maria Elisabete Rodrigues Freire Gasparetto ${ }^{1}$, Edméa Rita Temporini², Keila Miriam Monteiro de Carvalho ${ }^{3}$

\begin{abstract}
Objective: To assess the prevalence of diabetic retinopathy and to evaluate the management of patients with visual disabilities attending at the CEPRE Rehabilitation Program of University of Campinas. Methods: A retrospective study was carried out based on medical records of patients with visual disabilities attending a vision rehabilitation program. The following variables were studied: gender, age, marital status, level of schooling, social security status, origin, type and cause of visual disability and vision rehabilitation actions. Results: The sample consisted of 155 patients, $55.5 \%$ males, aged between 12 and 88 years, mean age 41 years old, $34.8 \%$ were blind and $65.2 \%$ with low vision disability. Of those blind patients, $81.8 \%$ reported acquired blindness, and the leading cause was diabetic retinopathy (33.3\%), followed by glaucoma (16.6\%), and retinal detachment $(15.0 \%)$. Of those patients with low vision disability, $14.9 \%$ had diabetic retinopathy, $14.9 \%$ hereditary syndromes, and $10.9 \%$ age-related macular degeneration. Vision rehabilitation therapy included interdisciplinary team consultations helping patients go through the mourning process for the loss or impairment of vision, and promoting the enhancement of their skills for performing activities of daily living independently. The management of patients with low vision was also focused on vision rehabilitation. Conclusion: The health of the eyes of patients with chronic diseases such as diabetes is at risk. The prevalence of diabetic retinopathy was found to be a cause for visual disability, suggesting the need to assess these patients' access to health care and rehabilitation and promote health education for changing habits and improving quality of life.
\end{abstract}

Keywords: Diabetes mellitus; Blindness; Vision, low; Vision disorders/rehabilitation; Quality of life

\footnotetext{
'Departamento de Desenvolvimento Humano e Reabilitação, Centro de Estudos e Pesquisas em Reabilitação "Prof. Dr. Gabriel Porto" da Faculdade de Ciências Médicas da Universidade Estadual de Campinas - UNICAMP - Campinas (SP) - Brazil. ${ }^{2}$ Disciplina de Oftalmologia, Faculdade de Medicina da Universidade de São Paulo USP - São Paulo (SP), Brazil.

${ }^{3}$ Departamento de Oftalmologia e Otorrinolaringologia da Faculdade de Ciências Médicas,da Universidade Estadual de Campinas UNICAMP - Campinas (SP) - Brazil.
}

Interest conflitct - None

Study carried out at Prof. Dr. Gabriel Porto Center for Rehabilitation Studies (CEPRE) - Faculdade de Ciências Médicas - Universidade Estadual de Campinas - UNICAMP - Campinas (SP), Brazil

Recebido para publicação em: 30/12/2010 - Aceito para publicação em 11/4/2011

Rev Bras Oftalmol. 2011; 70 (6): 342-8 


\section{ReSUMO}

Objetivo: Verificar a prevalência da retinopatia diabética e as condutas desenvolvidas entre deficientes visuais atendidos pelo Programa de Reabilitação no CEPRE da Universidade Estadual de Campinas. Métodos: O estudo retrospectivo transversal foi desenvolvido a partir da análise de prontuários de pacientes que participaram do programa de reabilitação de deficientes visuais, considerando-se as variáveis: sexo, idade, estado civil, escolaridade, situação de seguridade, procedência, tipo e a causa da deficiência visual e condutas reabilitacionais. Resultados: A casuística constou de 155 pacientes, $55,5 \%$ do sexo masculino, faixa etária entre 12 e 88 anos, média de idade de 41 anos, 34,8\% cegos e 65,2\% com baixa visão. Dos cegos, $81,8 \%$ tinham cegueira adquirida, sendo a retinopatia diabética (33,3\%) a causa prevalente da cegueira, seguida por glaucoma (16,6\%) e descolamento de retina (15,0\%). Dos pacientes com baixa visão, $14,9 \%$ apresentavam a retinopatia diabética e síndromes hereditárias somaram $14,9 \%$, seguido pela degeneração macular associada à idade (10,9\%). As condutas reabilitacionais desenvolvidas para os pacientes com deficiência visual constaram de atendimentos com equipe interdisciplinar propiciando a elaboração do luto pela perda ou diminuição visual, potencializando as habilidades para o desempenho independente e autônomo nas atividades do cotidiano. Entre os pacientes com baixa visão, as condutas enfocaram a reabilitação visual. Conclusão: Doenças crônicas como o diabetes constituem risco para a saúde ocular. Destacou-se a prevalência da retinopatia diabética entre as causas da deficiência visual, indicando a necessidade de se avaliar o acesso ao atendimento médico e às ações de reabilitação e educação em saúde favorecendo as mudanças de hábitos e qualidade de vida dos pacientes.

Descritores: Diabetes mellitus; Cegueira; Baixa visão; Transtornos da visão/reabilitação; Qualidade de vida

\section{INTRODUCTION}

I $\mathrm{n}$ recent decades thousands of people have been affected by diabetes mellitus (DM) worldwide regardless of their social condition ${ }^{(1)}$ placing a growing burden to health systems. Diabetes is a leading non-communicable chronic disease with sudden and insidious onset, and may be associated with the risk of cardiovascular complications and high morbidity and mortality rates. Despite scientific advances and improved quality of care, diabetes remains a public health concern in both developed and developing countries. The globally increasing prevalence of diabetes has been attributed to modern lifestyle, which can lead to obesity, physical inactivity, and consumption of high-fat, high-calorie diet ${ }^{(2)}$. Studies have pointed diabetes as a major cause of blindness, kidney failure and limb amputation. These complications can result in significant health costs and lead to reduced work capacity and life expectancy of those affected ${ }^{(3)}$, impairing their quality of life. It is estimated that 7 to $8.0 \%$ of the world population have DM. It is thus a serious health problem with significant socioeconomic impact ${ }^{(4)}$.

The World Health Organization (WHO) reported 150 million people with diabetes worldwide, a figure that is expected to double by 2025 mainly in developing countries due to population aging, unhealthy eating habits, obesity, and sedentary lifestyle ${ }^{(5)}$.

DM affects $7.6 \%$ of the brazilian population between 30 and 69 years of age ${ }^{(6)}$. Studies have reported that about $50.0 \%$ of diabetic patients were not aware of their status and $24.0 \%$ of those who were aware knowingly choose not to take care of themselves ${ }^{(7)}$.

Diabetic retinopathy is a severe consequence of DM arising during the course of the disease ${ }^{(8)}$ and can lead to permanent vision loss. It is the leading cause of blindness in Europe and the United States and also accounts for vision loss and blindness in adults in developed countries ${ }^{(9)}$. A similar pattern is seen in Brazil. Diabetic retinopathy is a major cause of irreversible visual impairment in working-age adults ${ }^{(10,11)}$. According to the Brazilian Ministry of Health, it accounts for $4.5 \%$ of all cases of visual disabilities ${ }^{(12)}$, affecting approximately $40.0 \%$ of diabetic patients.

Rehabilitation programs for the visually impaired have helped improve their quality of life ${ }^{(13)}$. These programs include actions set out in health policies and are provided by the Brazilian National Health System aiming at restoring partial or full capacity over the course of the disease and facilitating re-inclusion of these patients into the social environment and work market ${ }^{(14)}$.

The Prof. Dr. Gabriel Porto Center for Rehabilitation Studies (CEPRE) is dedicated to the rehabilitation of patients with sensory disabilities, providing them comprehensive care with a view to facilitating re-inclusion into their family, social, and work environment. CEPRE provides care to blind and low vision patients of different ages through several interdisciplinary rehabilitation actions.

The objective of the present study was to assess 
the prevalence of diabetic retinopathy and to evaluate the management of patients with visual disabilities attending the CEPRE rehabilitation program regarding their level of independence and quality of life.

\section{Methods}

A retrospective study was conducted in CEPRE, and data was collected for the period between may 2004 and april 2008. During this period there were 15 rehabilitation groups of patients with visual disabilities: six groups of blind patients and 9 of low vision patients. Group activities were performed by a multidisciplinary team comprising ophthalmologists, education specialists, psychologists, occupational therapists, social workers, nutritionists, and specialists in activities of daily living and information technology. Data was collected from medical records of all patients in the rehabilitation groups on following sociodemographic variables: gender, age, marital status, level of schooling, social security status, origin, type and causes of visual disability and vision rehabilitation actions.

\section{ResUlts}

A total of 155 patients were studied, of which $55.5 \%$ were males $(n=86)$ and $44.5 \%$ females $(n=69)$ with age ranging between 12 and 88 years old, mean age 41 years old $(\mathrm{SD}=17.7)$. Table 1 shows sociodemographic characteristics of the patients studied. Most patients were married $(50.0 \%), 35.0 \%$ single, $10.7 \%$ separated, and $4.3 \%$ widowed. More than $50 \%$ had incomplete elementary education, $25.4 \%$ had complete middle/high school education or higher and $6.2 \%$ were functionally illiterate. Regarding their employment and social security status, $32.0 \%$ were retired, $22.2 \%$ were receiving medical leave benefits, $10.7 \%$ were receiving disability benefits from social security, $9.2 \%$ were regularly employed, $5.3 \%$ were unemployed and received no social security benefits, and $10.6 \%$ were dependents of their family.

The majority $(59.3 \%)$ of the patients studied were living in the city of Campinas and its metropolitan area.

Of all patients with visual disabilities, $34.8 \%$ were blind $(\mathrm{n}=54)$ and $65.2 \%$ had low vision $(\mathrm{n}=101)$. Among blind patients, $81.8 \%$ reported acquired blindness, and the leading cause of blindness was diabetic retinopathy $(33.3 \%)$, followed by glaucoma $(16.6 \%)$, and retinal detachment (15.0\%). Among low vision patients, $14.9 \%$ had diabetic retinopathy, $14.9 \%$ hereditary syndromes, and $10.9 \%$ age-related macular degeneration (Table 2).

Blind patients with diabetic retinopathy were between 22 and 76 years old, and $76.0 \%$ were 41 to 70 . Most were undereducated, i.e., $56.0 \%$ did not complete elementary school. Low vision patients with diabetic retinopathy had visual acuity ranging from 20/200 to 20/ 400 , their age ranged between 28 and 79 years old, most being 28 to 60 . Regarding their level of schooling, $33.5 \%$ reported complete middle/high school education and $25.0 \%$ college education, while the remaining had complete elementary education.

The interdisciplinary team staff at first worked individually with blind patients to help them go through the mourning process for the loss of vision. They worked to enhance the patients' sensory abilities of touch, smell, hearing, taste and proprioception, helping them relearn how to interact and get involved with the surrounding environment. They performed activities to develop tactile discrimination aimed at learning the Braille system, promoting reading and writing communication. As for orientation and mobility skills, patients received training in the use of a cane and information about guide dogs and accessibility. Sound software programs were also used in this training (Table 3).

Low vision patients were encouraged to use their residual vision enhanced by optical aids prescribed by the ophthalmologist, together with non-optical aids such as adaptations in the light environment, enlarged images, use of contrast, among others. The patients were individually evaluated as for their orientation and mobility skills bearing in mind their needs and degree of visual impairment. Sound and amplification software programs were used (Table 4).

All blind and low vision patients received psychological and social support and were given opportunities to share their difficulties in group situations, or even individually as needed. They also received nutritional guidance focused on specific aspects of their condition.

\section{Discussion}

Several epidemiological studies have confirmed that diabetes is one of the most prevalent noncommunicable diseases and the fourth or fifth leading cause of death in most developed countries. Diabetes affects nearly every organ in the human body and is a major cause of blindness and lower limb amputation at great economic and social cost to patients and society ${ }^{(15)}$. The socioeconomic impact of diabetes constitutes a public health problem as its complications reduce productive life of diabetic patients affecting their own and their family's quality of life ${ }^{(4)}$. Despite widespread awareness campaigns for prevention of diabetes and its complications, diabetes has become an epidemic. Acquired diabetic retinopathy can be prevented through knowledge and information on the disease; however, the fact that patients are uninformed and undereducated may create an important barrier for primary and secondary prevention of diabetes, which will have a direct impact on their eye health.

Several diabetes prevention programs in Brazil 
Table 1

Sociodemographic characteristics of patients attending a rehabilitation program at a university center

\begin{tabular}{|c|c|c|c|}
\hline \multicolumn{3}{|l|}{ Variables } & \multirow{2}{*}{$\begin{array}{r}\% \\
55.5\end{array}$} \\
\hline \multirow[t]{2}{*}{ Gender } & $M=86$ & & \\
\hline & $F=69$ & & 44.5 \\
\hline Age & $12-88$ years old & \multicolumn{2}{|l|}{$\begin{array}{l}\text { Mean: } 41 \\
(\mathrm{SD}=17.7)\end{array}$} \\
\hline \multirow{6}{*}{ Level of schooling } & Illiterate & & 6.2 \\
\hline & Incomplete eler & tary education & 50.0 \\
\hline & Complete elem & ary education & 8.4 \\
\hline & Incomplete mid & /high education & 10.0 \\
\hline & Complete midd & igh education & 14.6 \\
\hline & College educati & & 10.8 \\
\hline \multirow[t]{4}{*}{ Marital status } & Single & & 35.0 \\
\hline & Married & & 50.0 \\
\hline & Separated & & 10.7 \\
\hline & Widowed & & 4.3 \\
\hline \multirow[t]{6}{*}{ Social security status } & Medical leave b & fits & 22.2 \\
\hline & Employed & & 9.2 \\
\hline & Retired & & 32.0 \\
\hline & Social security 1 & efits & 10.7 \\
\hline & Dependent of $\mathrm{t}$ & amily & 20.6 \\
\hline & Unemployed & & 5.3 \\
\hline \multirow[t]{4}{*}{ Origin } & City of Campin & & 39.3 \\
\hline & Metropolitan ar & of Campinas & 20.0 \\
\hline & Other cities in $\mathrm{t}$ & state of São Paulo & 35.5 \\
\hline & Other Brazilian & tes & 5.2 \\
\hline
\end{tabular}

Table 2

Type and cause of visual disability in patients attending rehabilitation program at a university center

\begin{tabular}{lcccc}
\hline \multirow{2}{*}{ Cause } & \multicolumn{4}{c}{ Type of visual disability } \\
& $\mathbf{N}=\mathbf{5 4}$ & $\mathbf{( 3 4 . 8 \% )}$ & Low vision \\
& $\mathbf{N}=\mathbf{1 0 1}$ & $\mathbf{( 6 5 . 2 \% )}$ \\
\hline Diabetic retinopathy & 18 & 33.3 & 15 & 14.9 \\
Hereditary syndromes & 04 & 7.4 & 15 & 14.9 \\
Glaucoma & 09 & 16.6 & 07 & 6.9 \\
Retinitis pigmentosa & 04 & 7.4 & 10 & 9.9 \\
Retinal detachment & 08 & 15.0 & 03 & 2.9 \\
Macular degeneration & & & 11 & 10.9 \\
Chorioretinitis & & & 10 & 9.9 \\
Cataract & 01 & 1.8 & 05 & 4.9 \\
Trauma & 04 & 7.4 & 01 & 1.0 \\
Other & 06 & 11.1 & 24 & 23.8 \\
\hline
\end{tabular}


Table 3

Activities for blind patients attending rehabilitation program at a university center

\begin{tabular}{|c|c|}
\hline Staff & Activities \\
\hline \multirow[t]{2}{*}{ Social worker } & Welcomes and supports blind patients and their family to continue their life project; \\
\hline & $\begin{array}{l}\text { Provides guidance on social security, welfare and other social benefits/rights: right to } \\
\text { work; disability rights, competitive examination, social cooperatives, internship, } \\
\text { apprenticeship, temporary job, work-experience contract; Helps them with social } \\
\text { problems that affect their rehabilitation. }\end{array}$ \\
\hline Psychologist & $\begin{array}{l}\text { Helps them go through the mourning process for the loss of vision; Works with them } \\
\text { to construct a new identity of a blind person; Helps them cope with their limitations } \\
\text { and frustrations. }\end{array}$ \\
\hline \multirow[t]{2}{*}{ Education specialist } & $\begin{array}{l}\text { Introduces the Braille system and helps those who wish to learn it; } \\
\text { Teaches patients how to use information technology such as sound software } \\
\text { programs; }\end{array}$ \\
\hline & Facilitates digital inclusion. \\
\hline Occupational therapist & $\begin{array}{l}\text { Encourages patients and family to express their feelings to facilitate the mourning } \\
\text { process for the loss of vision, skill development, and raising awareness of the potential } \\
\text { and development of independence in activities of daily living; Creates situational } \\
\text { activities and training taking into account the patients' needs;Organizes activities: } \\
\text { self-expression, drama, vocational, craft, recreation and leisure. }\end{array}$ \\
\hline Activities of daily living specialist & $\begin{array}{l}\text { Provides training for acquiring independence in daily life activities such as eating, } \\
\text { hygiene, clothing, home cleaning and management. }\end{array}$ \\
\hline Orientation and mobility specialist & Provides guidance on the use of a cane to ensure their right to mobility. \\
\hline Nutritionist & $\begin{array}{l}\text { Provides guidance on the importance of healthy eating and a snack is provided with } \\
\text { each session to reinforce this guidance. }\end{array}$ \\
\hline
\end{tabular}

Table 4

Activities for low vision patients attending rehabilitation program at a university center

\begin{tabular}{|c|c|}
\hline Staff & Activities \\
\hline Social worker & $\begin{array}{l}\text { Welcomes and supports low vision patients and their family to continue their life } \\
\text { project; Provides guidance on social security, welfare and other social benefits/rights: } \\
\text { right to work; disability rights, competitive examination, social cooperatives, internship, } \\
\text { apprenticeship, temporary job, work-experience contract; Helps them with social } \\
\text { problems that affect their rehabilitation }\end{array}$ \\
\hline Psychologist & $\begin{array}{l}\text { Helps them go through the mourning process for the loss of vision; Works with them } \\
\text { to construct a new identity of a blind person; Helps them cope with their limitations } \\
\text { and frustrations and their desire of recovering their "healthy sight" }\end{array}$ \\
\hline Education specialist & $\begin{array}{l}\text { Teaches patients how to use the optical aids prescribed by the ophthalmologist; } \\
\text { Encourages the use of residual vision in reading and writing and everyday activities; } \\
\text { Teaches patients how to use information technology such as sound software programs; } \\
\text { Facilitates digital inclusion. }\end{array}$ \\
\hline Occupational therapist & $\begin{array}{l}\text { Focusing on the mourning process for low vision, helps skill development, improve } \\
\text { self-confidence and self-esteem and use of residual vision; Creates situational activities } \\
\text { and training taking into account the patients' needs; Organizes activities: self- } \\
\text { expression, drama, vocational, craft, recreation and leisure. }\end{array}$ \\
\hline Activities of daily living specialist & $\begin{array}{l}\text { Focusing on the use of their residual vision, provides training for acquiring } \\
\text { independence in activities of daily living such as eating, hygiene, clothing, home cleaning } \\
\text { and management. }\end{array}$ \\
\hline Orientation and mobility specialist & $\begin{array}{l}\text { Provides guidance on the use of a cane to ensure the right to mobility for patients } \\
\text { with visual impairment grade } 2 \text { (severe visual loss), grade } 3 \text { (profound visual loss) } \\
\text { and grade } 4 \text { (near total visual loss). }\end{array}$ \\
\hline Nutritionist & $\begin{array}{l}\text { Provides guidance on the importance of healthy eating and a snack is provided with } \\
\text { each session to reinforce this guidance. }\end{array}$ \\
\hline
\end{tabular}


include interventions for lifestyle changes and promotion of healthy diet and physical activity ${ }^{(16)}$.Some aspects of prevention that should be strengthened include diabetes screening and early diagnosis. Improved effective access to quality health care services, education and support of diabetic patients would greatly reduce the impact of the disease. Hence, most cases of blindness due to diabetic retinopathy could be prevented with appropriate actions for early diagnosis and adequate management of blood glucose and blood pressure. Diabetic retinopathy is a serious public health concern and requires a multidisciplinary approach for preventing further complications and consequent effects on the quality of life of patients.

From the 1990s international studies on diabetes health education and self-care have emphasized that providing information only to patients is not enough to assure adequate self-care; i.e., having knowledge on the disease is crucial but it alone does not ensure that patients will take proper care of themselves. Many factors related to attitudes, beliefs, values and perceptions are involved and influence a specific behavior and thus education actions are key for health promotion and can empower people to control their own eye health ${ }^{(17)}$. Despite the support of associations of diabetic patients, Brazilian patients still have limited knowledge on the potential complications of diabetes, such as retinopathy and blindness, with low coverage of diabetes prevention and screening ${ }^{(18-20)}$.

Many initiatives have been conducted in Brazil aimed at eye health promotion and blindness prevention $^{(19)}$ such as the cataract project and eye screening of schoolchildren, among others. Although thousands of patients of different ages have benefited from them, many people still do not have access to early diagnosis. Corroborating these data, we found in our study that the rehabilitation program for visually impaired persons have provided care to patients with diabetic retinopathy that might have been prevented through access to timely diagnosis and adequate treatment that prioritize education actions focused on self-care and proper diet, promotion of physical activities, and management of blood glucose levels, among others. It is estimated there are a considerable number of patients with diabetes who are undiagnosed and remain untreated for a long time ${ }^{(19)}$. The population assisted in CEPRE rehabilitation program are mostly undereducated, a finding that may be associated with lack of knowledge and neglect of self-care. Low socioeconomic condition can also be considered a health risk factor, pointing to the need for stronger public policies that prioritize prevention actions and treatment of this disease ${ }^{(21)}$.

Given that our sample comprised mostly primeage adults, mean age of 41 , a considerable proportion of them lived on social security benefits or depended on their family (Table 1), which bears a high social cost to the public care system and families.

The acquired visual impairment has an enormous impact on the lives of those affected and these patients can present different responses to their visual loss. Ophthalmologists must be aware and understand their specific needs and refer them to other rehabilitation providers as it is important to assess the stage the patients are going through in their school, work and family life and take it into consideration in the rehabilitation plan ${ }^{(22)}$.

Fletcher ${ }^{(23)}$ claims that, even in those cases that there is not much to be done to save the cornea, retina or optic nerve, much can be done to improve these patients' functionality of vision and quality of life.

The greater the visual loss, the greater the functional impact and the earlier rehabilitation is initiated, the better the adaptation and the least damaging the consequences will be to one's life ${ }^{(24)}$.

The art of rehabilitation is to convert a condition into the least possible disadvantage ${ }^{(25)}$. Promote independent living for visually impaired people is the main goal of the rehabilitation process, achieved through an interdisciplinary team approach and different actions taking into consideration individual needs.

Rehabilitation has provided blind patients means for reinserting into their social environment with greater independence and improved quality of life ${ }^{(26)}$.

The activities with patients with low vision (Table 4) aimed at an effective use of vision in everyday tasks ${ }^{(26)}$. The use of residual vision is not always instinctive ${ }^{(23)}$ to patients and vision rehabilitation require the use of optical and non-optical aids as well as electronic and information technology resources.

People with low vision will only use optical aids if they are affordable and meet their daily living needs. ${ }^{(24)}$

Study developed in $2004{ }^{(27)}$ found that $54.8 \%$ of patients attending the Low Vision Service (LVS) at Universidade Estadual de Campinas were prescribed optical aids. Optical aids were not prescribed for those patients who no longer performed activities of reading and writing, those who considered their level of vision satisfactory to perform everyday activities, those who had high-grade myopia with visual acuity at close-up of $1 \mathrm{M}$ or $0.8 \mathrm{M}$ (being able to read words in newspapers/magazines) and those with very severe eye disease.

Data from medical records of patients with low vision showed that in early rehabilitation they expressed difficulty in performing daily activities after visual loss, and that because of the challenges and lack of adequate guidance, they used less their vision and thus became 
less independent requiring help. Vision rehabilitation of these patients aimed at supporting the use of aids prescribed in the LVS in activities of daily living that they no longer performed.

A barrier to the use of residual vision and optical aids was identified from medical records. Some patients believed in the myth that moving the eyes closer to things and using their vision could be harmful to the eyes and speed up the progress of their eye condition.

\section{Conclusion}

The health of the eyes of patients with chronic diseases such as diabetes is at risk. Rehabilitation was found to have a positive impact on the lives of blind and low vision patients in our study. The study findings together with the prevalence of diabetic retinopathy found in this study reinforce the need for redirecting public policies combined with education and health actions to improve current eye health in Brazil.

\section{ReferenCeS}

1. Assunção MCF, Santos IS, Gigante DP. Atenção primária em diabetes no Sul do Brasil: estrutura, processo e resultado. J Public Health. 2001;35(1):88-95.

2. Narayan KM, Gregg EW, Fagot-Campagna A, Engelgau MM, Vinicor F. Diabetes - a common, growing, serious, costly, and potentially preventable public health problem. Diabetes Rev Clin Pract. 2000; 50 Suppl 2:S77-84.

3. World Health Organization. Prevention of diabetes mellitus. Report of a WHO Study Group. Geneva: World Health Organization; 1994. (WHOTechnical Report Series, 844).

4. Bosco A, Lerário AC, Soriano D, Santos RF, Massote P, Galvão $\mathrm{D}$, et al. Retinopatia diabética. Arq Bras Endocrinol Metab. 2005;49(2):217-27.

5. World Health Organization. Media Centre. Diabetes mellitus. Fact sheet No138. [cited 2011 Mar 23]. Available from: http://www.who.int/mediacentre/factsheets/fs138/en/

6. Gross JL, Nehme M. Detecção e tratamento das complicações crônicas do diabetes melito: Consenso da Sociedade Brasileira de Diabetes e Conselho Brasileiro de Oftalmologia. Rev Assoc Med Bras (1992). 1999;45(3):279-84.

7. Malerbi DA, Franco LJ. Multicenter study of the prevalence of diabetes mellitus and impaired glucose tolerance in the urban Brazilian population aged 30-69 yr. The Brazilian Cooperative Group on the Study of Diabetes Prevalence. Diabetes Care. 1992;15(11):1509-16.

8. Bognetti E, Calori G, Meschi F, Macellaro P, Bonfanti R, Chiumello G. Prevalence and correlations of early microvascular complications in young type I diabetic patients: role of puberty. J Pediatr Endocrinol Metab. 1997;10(6):587-92.

9. Nakanami C. O que dizer da biodiversidade regional e o que implica? Bol Visão 2020 América Latina. [citado 2011 Mar 23]. Disponível em http://www.v2020la.org/bulletin/port/docs/ boletin_11/docs/pdf/tema7.pdf

10. Aiello LP, Gardner TW, King GL, Blankenship G, Cavallerano JD, Ferris FL 3rd, Klein R. Diabetic retinopathy. Diabetes Care. 1998;21(1):143-56. Review.
11. Adam Netto A, Wayhs LF, Santos Júnior EC. Diagnósticos emergenciais em oftalmologia em um hospital universitário. Rev Bras Oftalmol. 2002;61(12): 877-83.

12. Pereira DS, Reis FAC, Waetge RTL, Caliari LE, Aihara T. Prevalência da retinopatia diabética no Ambulatório de Endocrinologia Pediátrica da Santa Casa de Misericórdia de São Paulo. Arq Bras Oftalmol. 2004;67(1):111-4.

13. Bittencourt ZZL, Hoehne EL. Qualidade de vida de deficientes visuais. Medicina (Ribeirão Preto). 2006;39(2):260-4.

14. Buss PM. Promoção da saúde e qualidade de vida. Ciênc Saúde Coletiva. 2000;5(1):163-77.

15. Disdier-Flores OM, Rodríguez-Lugo LA, Pérez-Perdomo R, Pérez-Cardona CM. The public health burden of diabetes: a comprehensive review. P R Health Sci J. 2001;20(2):123-30.

16. Toscano CM. As campanhas nacionais para detecção das doenças crônicas não-transmissíveis: diabetes e hipertensão arterial. Ciênc Saúde Coletiva. 2004;9(4):885-95.

17. Temporini ER, Kara-José N, Gondim EL, Dantas FJ. Conhecimentos sobre saúde ocular entre profissionais de um hospital universitário. Medicina (Ribeirão Preto). 2002;35(1):53-61.

18. Ramos SR, Sabbag FP, Busato D, Miranda AB, Moreira Júnior CA. Retinopatia diabética: estudo de uma associação de diabéticos. Arq Bras Oftalmol.1999;62(6):735-7.

19. Silva VB, Temporini ER, Silva HMB, Moreira Filho DC, KaraJosé N. Retinopatia diabética: percepções e condutas do paciente em relação a possibilidades de tratamento. Rev Bras Oftalmol. 2001;60(2):133-8.

20. Silva VB, Temporini ER, Moreira Filho DC, Kara-José N. Tratamento da retinopatia diabética: percepções de pacientes em Rio Claro (SP) - Brasil. Arq Bras Oftalmol. 2005;68(3):363-8.

21. Temporini ER, Kara -José N. A perda da visão: estratégias de prevenção. Arq Bras Oftalmol. 2004;67(4):597-601.

22. Costa Filho HA. Histórico da atenção à pessoa com deficiência visual. In: Sampaio MW, Haddad MAO, Costa Filho HA, Siaulys MOC. Baixa visão e cegueira: os caminhos para a reabilitação, a educação e a inclusão. Rio de Janeiro: Guanabara Koogan; 2010. p. 3-6. Ok - só livro

23. Fletcher DC. Low vision rehabilitation: caring for the whole person. San Francisco: American Academy of Ophthalmoly; 1999.

24. Fernandes LC. Reabilitação visual do indivíduo com baixa visão irrecuperável e cego: reabilitação visual: o que é, como e quando ocorre. In: Kara-José N, Rodrigues MLV. Saúde ocular e prevenção da cegueira. Rio de Janeiro: Cultura Médica; 2009. p.155-9.

25. Colembrander A. Reabilitação de baixa visão. In: Veiztman S. Coleção de manuais básicos CBO: visão subnormal. São Paulo: Cultura Médica; 1998. p. 87-109.

26. Montilha RCI, Temporini ER, Nobre, Kara-José N. Deficiência visual: características e expectativas da clientela de serviço de reabilitação. Rev Ciênc Méd (Campinas). 2000;9(2):123-8.

27. Carvalho KM, Monteiro GBM, Isaac CR, Shiroma LO, Amaral MS. Causes of low vision and use of optical aids in the elderly. Rev Hosp Clin Fac Med Univ São Paulo. 2004;59(4):157-60.
Endereço para Correspondência:
Zélia Zilda Lourenço de Camargo Bittencourt
Rua Tessalia Vieira de Camargo, $n^{\circ} 126$
CEP 13083-887 - Campinas - São Paulo (SP), Brasil
Tel:(19)3521-8817
E mail: zeliaz@fcm.unicamp.br 